\title{
The Actualization of Local Cultural Values in Governance Leadership of Palopo City
}

\author{
Andi Lukman Irwan \\ Department of Politics and Government, Hasanuddin University, Makassar, Indonesia \\ Corresponding author: andilucky@yahoo.com
}

\begin{abstract}
This paper aims to determine and describe how the understanding of government leaders about local cultural values, how the actualization of local cultural values in government leadership, and the influence of structural positions in actualizing local cultural values in Palopo city. Data collection methods used was observation, interview, and document study, while the data are analyzed qualitatively. The concept of local autonomy in its implementation does not guarantee the existence of local cultural values in local governance especially in Palopo city, related to local cultural values variables such as adele, lempu, and getteng, to the understanding and actualization of the value in performing main tasks and functions as government leaders.
\end{abstract}

Keywords-governance, leadership, local culture

\section{INTRODUCTION}

Indonesia is a pluralistic nation which can be seen from the following parameters: first, the existence of cultural diversity (multicultural); second, ethnic alliance, and third, ethnically organized [1]. In a multi-ethnic or multi-cultural society such as Indonesia, pluralism not only implies differences, but also contains mutual interactions among community members. In such societies, the problem that usually arises is the difficulty of reaching agreement in placing the foundation of an established system of government, and also the increasingly lack of ethics of morality in the life of society and within the scope of government itself [2].

Luwu as region located on the northern edge of South Sulawesi, besides known for its abundant natural products (agriculture, plantations, nickel mines, etc.) also has an interesting historical. The Book I Lagaligo is the literary text of the kingdom of Luwu and still preserved its authenticity as proof of how the kingdom of Luwu has an intellectual tradition. In addition to the Book I Lagaligo, several other relics reinforce the greatness of Luwu such as buildings of kingdom, mosques, tombstones, and others [3].

Ada Asera (adat sembilan) performing legislative functions, in which they are all representatives of the people. Ada Asera consists of anak tellue such Opu Ma'dika Ponrang, Opu Ma'dika Bua, and Opu Ma'dika Baebunta. In addition to Anak Tellue, there is also Bendera Tellue, which is representative of soldiers, workers, and noble children.

Reinventing the cultural identity of Luwu become a "must" to be done is not only the younger generation but all elements of Luwu society including the government. A foreign culture that hegemonized, causing the alienation of Luwu youth in their surrounding environment. This alienation is due to foreign culture that comes as the result of manipulation to exploit the society economically. It is characterized by the decline of local cultural values that should be a guide in behaving in life, now only limited knowledge of the layman, even ironically the values local culture can be forgotten.

\section{RESEARCH METHOD}

The collected data will be analyzed descriptively with qualitative approach according to the number of variables used as indicator in this research and supported by secondary data [4]. Data collection methods used was observation, interview, and document study. Then the data are analyzed qualitatively.

\section{RESULT AND DISCUSSION}

The following description on the government leaders in Palopo city understands the local cultural values of adele, lempu, and getteng, in organizing the government [5]. For detail will be discussed in the following discussion.

\section{A. Adele}

Universally the concept of justice can be widely known by every society, including government' leaders. The leaders know that justice is a non-discriminating and equitable service to every society [6]. However, in accordance with the intent and purpose of this study which tries to raise local wisdom as a philosophy or a special spirit in managing the government needs an understanding of the existence of this value in the culture of a nation or region, especially for the leaders.

Some informants revealed clearly that he had never heard of any value in the meaning of this subject. This is marked when the author tries to ask the informant about the existence of this local value before stepping into the question and answer process, and the informant has not heard of any local value adele. The government leaders can know the existence of local value after the author describes the value of local culture adele.

Meanwhile, in the process of understanding the initial stage that must be fulfilled is knowledge about the concept of local cultural values adele, and indirectly on the basis of ignorance, because previously never heard or recognized the value of adele, then in this stage the leader has fallen. 
Provides guidance and direction to subordinates equally to all subordinates and in accordance with their respective capabilities. Then evaluate their performance in order to develop career fairly and without discrimination. Then the determination of policy in order to delegates the authority to the subdistrict head is done equally and in accordance with the needs of the conditions at that time.

As the interview result with the Head of Culture and Tourism Office of Palopo, in actualizing the local cultural values of lempu as its duties and function related to distribution and instructions to perform tasks to subordinates and evaluate their work. This is seen from his explanation which reveals that accommodate all employees in the Department of Culture and Tourism in accordance with the functions and competencies of each without comparing or discriminating on the basis of personal closeness.

The author conclude one form of actualization of local values adele in terms of developing and coordinating cooperation with private parties in managing the potential of tourism resources in Palopo in which to determining the agreement on the management of tourist sites, some community representatives called to provide input as a consideration for the interest of people around the tourist sites remains in priority.

\section{B. Lempu}

Lempu (honest) in the context of local cultural values derived from the kingdom of Luwu. As the definition of understanding, can be seen that one can be said to understand when fulfilling the stages in the process of understanding consisting of know, then continued with translation or interpretation, to the stage of extrapolation or the development of the meaning of a concept. As the results of interviews with the subdisstrict head of Telluwanua, the achievement of understanding of the value of lempu has reached the stage of extrapolation; it is marked by the author when he was able to develop the meaning of lempu value based on the message conveyed to him through his parents.

As the result of interview, it can be concluded that in the case of understanding of subdistrict head of Telluwanua and Head of Department is a leader who still understands the local values that are intended in this paper. With an indication that he had previously recognized the local value from other peoples' information, and assumed that the value was very important to be understood by every leader especially in Palopo city. The value of lempu that is understood by the informant is not to say a lie, run the mandate that has been given to him, do not take the goods that are not his right, straighten problematic things and put something in place.

As the interview result with the subdistrict head of Telluwanua in actualizing the value of getteng in accordance with the main tasks and function of a subdistrict head that is carrying out all the mandate and responsibility that has been given in organizing the government at the subdistrict level. It is marked from his existence which is still consistent in serving his position as subdistrict head. Until now, the giving of instructions and direction to subordinates openly. Evaluation and performance assessment of subordinates is openly.
Delegation of authority based on the ability of the village head. Straighten or mediate issues of land disputes honestly. Participate in cleaning the environment with the community. Report the results of execution of duties honestly and candidly.

In relation to the main tasks and function of the Head of Culture and Tourism Office of Palopo in actualizing the value of lempu as the mentioned results of interviews, implemented in terms of distribution of tasks based on ability without covering something and giving instructions to perform tasks to subordinates and evaluate the results of its work openly and candidly. The interesting is the implementation of duties and responsibilities as Head of Department as a mandate given by superiors. In addition, maintaining cooperative relations and coordination with other agencies or organizations in making an activity or agreement that includes the areas of customs, arts and tourism.

\section{Getteng}

As the value of adele and lempu, the understanding of getteng value by some informants who are government leaders in Palopo city, in this paper is only limited to the common understanding, in the sense that they are not able to interpret really based on the concept taught in the kingdom of Luwu. The concerned informants were village head of Sampoddo, Jaya, Lagaligo, South Wara, Wara and Deputy Mayor of Palopo. It can be indicated when in the interview process, the author tries to ask all informants as the beginning or introductory interview about the existence of local values getteng and other values. But the existing conditions, they had never heard or recognize the value, they can know after getting a picture from the author.

Related to the main tasks and function of the subdistrict head of Telluwanua, the actualization of local values of getteng can be known in terms of preparation of plans and work programs based on their main tasks and functions. In the governance, development and community building in accordance with the authority delegated by the Mayor in the form of solid firmly to the responsibilities given by superiors and in accordance with established rules.

As the understanding of the Head of Culture and Tourism Office about the value of getteng (tenacious) represents a trait that symbolizes consistency and firmness. When synchronized with the main tasks and function through the result of author' interview that the actualization of getteng value can be seen from his consistency in exercising the mandate and responsibility as Head of Department. The firmness in making policies and agreements between various parties, then in the agreement that has been made remain a handle in the act and assess according to the agreement.

\section{Influence of Governmental Status in Actualizing the Local Culture Value}

In this discussion, the position in government is a position based on the hierarchy of structural positions within the district/city government, which is called the level of echelon, and especially in Palopo city. Initial hypothesis of this research is there is difference of quantity and quality of actualization of local cultural value of adele, lempu and getteng by government 
leaders in exercising the main tasks and function according to each position. Said that the higher the position of a leader the greater the index of actualization of local cultural values, or the greater the area of position the greater the index of actualization of local value. Otherwise, the lower the position or the smaller of leadership area, the smaller and narrower the index of actualization of local cultural values.

However, as author' conclusions obtained during this research found that there was no effect of differences in position or structural position of government leaders in actualizing the local cultural values of adele, lempu and getteng. It is based on the findings of authors that all government leaders included in this study and included in the structural positions of the level of echelon, in which only 2 (two) are actualizing the value and of course initiated with an understanding of the value itself. So that 2 (two) leaders are not representative of the hierarchy of structural positions of echelon level and make the structure is no longer in accordance with the results obtained.

\section{CONCLUSION}

Principally, local autonomy in the implementation of local government is intended to bring the government closer to the existing community in the region, by granting management authority of local government itself. As the results of research, it is found that the concept of local autonomy in its implementation does not guarantee the existence of local cultural values in governance in the region especially in Palopo city, related to local cultural values of adele, lempu, and getteng, towards the understanding and actualization of the value in exercising the main task and function as the government leaders.

\section{REFERENCES}

[1] IRE, 2002, Desentralisasi dan Demokrasi Lokal: Anual Reeport 2001, Yogyakarta: Penerbit IRE, 2002.

[2] T. Ndraha, Kybernology 2 Jakarta: Asdi Mahasatya,2002.

[3] S.D. Mallondjo, Kedatuan Luwu, Catatan Tentang Sawerigading, Sistem Pemerintahan dan Masuknya Islam, Palopo: Pustaka Sawerigading, 2008.

[4] B.M. Miles, and A.M. Huberman, Analisis Data Kualitatif, Jakarta: Universitas Indonesia Press, 1992.

[5] I. Anwar, Ensiklopedi Kebudayaan Luwu, Makassar: Pustaka Sawerigading, 2007.

[6] I.S. Kencana, Pengantar Ilmu Pemerintahan, Bandung: Refika Aditama, 2005. 